\title{
EXPLORING THE CULTURAL COGNITION AND THE CONCEPTUAL METAPHOR OF MARRIAGE IN INDONESIA
}

\author{
Joko Kusmanto
}

jokokusmanto@gmail.com

Politeknik Negeri Medan

Medan, Sumatera Utara, Indonesia

\begin{abstract}
This paper explores what cultural cognition of 'marriage' is metaphorically conceptualized in Indonesian expressions. This paper has two questions. Firstly, what cultural cognitions of 'marriage' are encoded in the use of metaphorical expressions in Indonesian? Secondly, how such cultural cognition of 'marriage' is metaphorically conceptualized in Indonesian expressions? The analysis and discussion of this exploration basically follow (i) the principles of embodiment in Cognitive Linguistics and (ii) the logic of cultural conceptualization in Cultural Linguistics. Both serve as the primary bases to analyze the problem of the study. The paper is expected to contribute to the present linguistic study in two-fold benefits. Firstly, it presents the discussion of the cultural cognitions of marriage represented in Indonesian metaphorical expressions. Secondly, it discusses the methodological issues of (i) how to understand the relation between culture and language and (ii) how to uncover any cultural representations in linguistic metaphors..
\end{abstract}

Keywords: metaphor, cultural cognition, marriage, Indonesian

\section{INTRODUCTION}

Meaning is undoubtedly the essence of language. It is "what language is for, to have a language without meaning would be like having lungs without air" (italics in original) (Riemer, 2010, p. 3). It is the language property that philosophers have never forgotten to ponder since Plato's Cratylus (385 BC) in which he discussed the nature of name - referent relationship (Kusmanto, 2013). The discussion was presented in the form of a dialog between Hermogenes standing on the conventionalist view and Cratylus standing on the naturalist view (Livington, 2015).

Despite its central position in language, the scientificity of studying linguistic meaning had also ever been questioned. The study of meaning was dismissed as a scientific study when "sensory experience" or "direct experience" was believed to be the sole authoritative source of obtaining a scientific knowledge. The positivistic epistemology in 1930s refused any study as a scientific study when it was not based on directly observed evidences (Bloomfield, 1933). But, one striking phenomenon in the study of meaning is that metaphorical expressions has always attracted philosophers for the first place and subsequently linguists, psychologists, and cognitivists to talk about it.

The first systematic study of linguistic metaphor has frequently been attributed to Aristotle (384 BC) (Kusmanto, 2014). However, there was a period when linguistic metaphor was considered to be solely a trope or figurative language which was appropriately attributed to the literary language. Yet, the use of metaphorical expression was once claimed to be a kind of language abuse. Locke (1690/1996, p. 498), for instance, clearly denounces that figurative language, "where truth and knowledge are concerned, cannot but be thought a great fault, either of the language or person that 
makes use of them". Figurative language, in other words, is a language use which will lead to unclear thinking and, hence, it is not appropriate as the means of gaining knowledge. Locke (1690/1996, p. 498) further views that

all ...... figurative application of words ...... are for nothing else but to insinuate wrong ideas, move the passions, and thereby mislead the judgment; and so indeed are perfect cheats

Metaphors are "the imperfections words" as they do not serve for what they really stand for, neither in civil nor philosophical discourse (Locke, 1690/1996, p. 465).

The expression that Locke has stated in the above quotes paradoxically is not in line with his own arguments. Words such as "move", "mislead", "cheat", and even "insinuate" are clearly metaphorically used (Goatly, 1997, p. 1). The notion of metaphor that Locke has understood seems to exclusively refer to the flowery expressions used metaphorically in literary works. He does not realize that there are plenty of conventionalized metaphors used in everyday language as he himself has provided in the above quoted expressions. Metaphors, such as "to get a good start", "a long life span", and "to go far in life" are so conventionalized and pervasive in everyday English that native speakers do not realize its metaphoricity anymore. They think that such expressions are normal and natural (Kovecses, 2010, p. $3)$.

The publication of Ortony's (1993) Metaphor and Though and Lakoff and Johnson's (1980) Metaphor We Live By mark the next milestone of the metaphor study. They have brought lots of philosophers, psychologists, cognitivists, and linguists as well back to focus on the central role of metaphor in language use and thought. Metaphor does not only constitute a trope which is exclusively attributed to literature language but also part of the everyday language use. The ubiquitous use of metaphor in everyday language use must have something to do with the structure of human mind which underlies it. In other words, metaphor provides us an evidence of "the creative interplay of language and thought" (Katz, 1998, p. 3). As language also constitutes a primary tool used by a group of people to transfer the values, symbols, interpretations, and perspectives of the social realities around them to their next generation, language highly bears cultural load. This further implies that investigating metaphor will be able to uncover simultaneously (i) how the underlying structure of human mind works and (ii) how culture is represented linguistically in metaphor.

\section{MEANING AS CONCEPTUALIZATION: FROM INDIVIDUAL INTO COLLECTIVE}

Meaning, both in terms of linguistic meaning and speaker's intention, is basically referential in nature. What I mean by 'referential' is that a linguistic expression which is transmitted by a speaker in a communication certainly refers to something outside the expression itself, be it concrete or abstract referent. Linguistic expressions at any level such as house, good boy, and it's raining outside refer something outside the expressions themselves. The first example refers to an identification, the second a definition, and the third a description (Sudaryanto, 1992). The expression house does not naturally constitute the entity being referred to, neither do the last two instances. It is in this sense that the term 'signification' is used by Saussure (1918) to show the arbitrary relationship between the linguistic expression and its referent. However, Saussure's (1918) model of signification is dyadic, consisting only of a form of the sign (the signifier) and its meaning (the signified). It implicitly depicts the signified or the referent as the direct and natural content of the symbol.

Since the relationship between the linguistic expression and its referent is arbitrary, there must be something that abstractly underlies in between the linguistic expression (symbol) and its referent as the real content. This abstract part is what Odgen and Richard (1946) called a 'concept' in their semiotic triangle comprising (i) symbol, (ii) concept, and (iii) referent. The notion of 'concept' is a mental representation of what something in the world is like. The notion of 'meaning' of a particular object, be it concrete or abstract, in the world is therefore closely linked to a particular mental representation 
(mental image) of a particular concept. The meaning of the word 'house' does not corresponds directly to a particular object in the world, rather it connects to the concept of 'what being a house is'. In other words, the notion of 'concept' goes further than mere reference.

When we are talking about 'a house', we all know what is meant by 'a house' in terms that we all have a certain mental representation of what 'a house' is like. But, if we have to draw a house, most probably we will not have the same picture of a house in all aspects. Despite the differences, we all still recognize and agree that all the pictures we have drawn are categorized as 'a house'. This indicates that the concept of an object called as a 'house' does not specifically refer to a specific kind of a house. We can use the semantic term "type" to refer to the term "concept" of the word house and "token' for all specific examples of the house. The houses may appear different in many respects such as their architecture, paint, and material, but they still fall into the same category. In a nut shell, the meaning construction of a particular object basically derives from the conceptualization of the object and is closely linked to the other human cognitive capacity called "categorization" (Evans, 2006); i.e. a process of treating distinct entities as somehow equivalent (Rosch, 1978). In shorts, linguistic meaning is equated with the result of a conceptualization (Geeraerts, 2006, p. 7; Langacker, 2000, p. 30).

As previously mentioned, conceptualization may be viewed as a meaning construction of a particular object in terms of how the objective nature of the object is conceptualized. This process results in a concept which is believed to be the objective meaning of the object. This kind of meaning is truthfully the concept of a particular object and will be the same across different cultural groups. The underlying assumption is that any concept produced from conceptualization is the product of the universal cognitive capacity implanted in every human brain. It is thought of being like different cameras which capture an object from the same angle (Kusmanto, 2014). Logically the pictures which have been taken by those cameras will be the same and that constitutes the truth of the content (meaning) of the object.
On the one hand, such conceptualization makes sense based on the fact that a certain concept of an entity is shared by all human beings as they are equipped with the same cognitive capacity. On the other hand, it brings us to imagine that our life and interaction with the world is static. The fact tells us in a different way. Our life and interaction with the world is very dynamic. None different social group is situated in the same territory in every respect. None different social groups also embrace the same social and demographic situation. This will lead them to have a kind of different interaction with their environment as a kind of different adaptation. In turn such differences will bring about different ways of understanding and interpreting the reality across different social groups. It is understood, then, that a collective conceptualization on a certain reality is the individual conceptualizations which have been schematized, i.e. "a process that involves the systematic selection of certain aspects of a referent scene to present the whole, disregarding the remaining aspects" (Talmy, 1983, p. 225). The members of a certain social group will relatively have the same general concept of a certain reality as a general image schema though in detail they may have different perceptions and interpretations. Sharifian (2011, p. 5) states that "although ... the locus of conceptualization may be the individual, a large proportion of concept-ualizations are ultimately 'spread' across a cultural group".

\section{COLLECTIVE CONCEPTUALIZATION AS CULTURAL COGNITION}

We have noticed that "conceptualizations that are expressed in natural language have an experiential basis, i.e., they link up with the way in which human beings experience reality, both culturally and physiologically" (Geeraerts, 2006, p. 27). Sharifian (2011, p. 47) stands on the same position saying that "human languages are indexes to conceptualizations that are largely derived from the cultural experience of their speakers". The term 'culture' here is briefly defined as "the shared knowledge and schemes created by a set of people for perceiving, interpreting, expressing, and responding to the social realities around 
them" (Lederach, 1995, p. 9). These shared knowledge and schemes can also be understood in terms of the collective conceptualizations explained above. As collective conceptualizations are shared by all members of a social group, those collective conceptualizations can be equated with "culturally collective cognition" of the members of a social group. The notion of "culturally collective cognition" used in this paper refers to Sharifian's (2011) notion of "culturally constructed conceptualization".

These culturally collective conceptualizations generally motivate different social groups to structure their language differently, be it syntactic or semantic. The cultural contents encrypted in linguistic expressions are often easily detected by those who study language and cultures that are not the same with their protolanguage. The linguistic expression in English (A) is easily detected by Indonesian that it depicts a sort of different concept in perceiving the reality.

(A) When I was peeling an apple, I cut my finger.

The use of the active voice construction $I$ cut my finger appears to be somewhat awkward to Indonesians who will have the passive voice construction for the same reality as in (B).

(B) Ketika saya sedang mengupas buah apel, jari saya teriris.

This difference does not occur by chance. The linguistic expressions (A) and (B) are the externalization of how speakers of English and those of Indonesian conceptualize their experience. Those linguistic expressions encode how speakers of different cultures perceive differently what they experience and, hence, conceptualize it from different perspective. The English expression (A) employs an active voice construction to show that it is the actor who is responsible for the accident. Even though it happens accidentally, it is the actor of the sentence (A) who still has to take the responsibility of the accident. In other words, the actor will have to take a look at her/himself and to think of what has caused her/him accidentally to cut her/his finger. On the other hand, the Indonesian expression (B) employs a passive voice construction and, generally, passive voice construction is used to hide the actor. It can be said that the speaker thinks that it is not her/his responsibility for this accident. It is not her/his fault. There may be a scapegoat to blame in this accident.

Though it is still an explorative conclusion, there are at least two arguments that can be presented to support it. First, the expression (A) and (B) are in line with their different material cultures respectively when they peel the apple. The speakers of utterance (A) have a kind of cognitive guide to peel the apple with a knife moving from the farther part of the fruit from the body of the speaker to the closer part. When mishap occurs, the knife will hurt the one who is doing the peeling and will not hurt other people who happen to be close to her/him. Meanwhile, the speakers of utterance (B) do it conversely. When mishap occurs, the knife will not hurt the one who is doing the peeling but will hurt other people who happen to be close to her/him. Secondly, such constructions are also found in other accidents as in (C) and (D).

(C) a. He felt down from his bike and he broke his leg.

b. The boy ran into the window and $\boldsymbol{h} \boldsymbol{e}$ broke his nose.

(D) a. Dia jatuh dari sepedanya dan kakinya patah.

'He/She felt down from his/her bicycle and his/her leg was broken'

b. Anak itu menabrak jendela dan hidungnya patah.

'The boy bumped into the window and his nose was broken'

Linguistic expressions (C) and (D) consistently encode and externalize the different thought as their different "culturally collective cognitions" of how different social groups perceive and interpret the same reality differently.

\section{CULTURAL COGNITION AND CONCEPTUAL METAPHOR}

It was said previously that linguistic expressions encode and externalize thoughts 
and ideas. Conceptualization does not always work to construct the meaning of a single entity in terms of the relation between a referent and its concept underlying it. Conceptualization also works to allow human being to perceive a reality of a certain domain in other domains such as (E).
(E)
a. His thoughts flow smoothly
b. The price moves up

The expression (E.a) conceptualizes the domain of THINKING in the domain of MOVEMENT OF CURRENT and (E.b) conceptualizes the domain of PRICE in the domain of DIRECTION. This association is linked based on the resemblance and embodiment. There is no real and physical resemblance between the activity of thinking on the one hand and the movement of current on the other hand. This resemblance is also the product of conceptualization representing how human being perceives the abstract entity thinking. In other words, the concept of THINKING ACTIVITY is understood based on the concept of MOVEMENT OF WATER. Hence, it is concluded that the metaphorical process takes place at the conceptual level and that is the brief explanation where the term "conceptual metaphor" comes from. Basically it is a conceptual mapping from the concept of MOVEMENT OF WATER into the concept of THINKING. In that conceptual mapping, the concept of MOVEMENT OF WATER is the source and concept of THINKING is the target.

The conceptual mapping which underlies the metaphors in (E) is apparently based on the embodiment and it also applies to Indonesian as in $(\mathrm{F})$.
a. Pikirannya mengalir dengan lancar.
b. Harga-harga mulai bergerak naik.

It means that the conceptual metaphor THINKING IS MOVEMENT OF WATER as reflected in linguistic metaphor (F.a) and (F.a) and conceptual metaphor PRICES ARE DIRECTION as reflected in linguistic metaphor (E.b) and (E.b) are not metaphors which are constructed on the basis of culturally specific conceptual mapping. Rather, it is from the fundamental cognitive process which operates in perceiving the reality on the basis of embodiment experience, "a species-specific view of the world due to the unique nature of our physical bodies" (Evans, 2006:45). At least English and Indonesian conceptualize realities depicted in (E) and (F) metaphorically in the relatively similar conceptual mapping as it is difficult to draw a conclusion the universality of conceptual mapping in metaphor only based on two languages (Kovecses, 2010:195).

Examples of conceptual metaphors which are based on the different cultural cognitions are presented in $(\mathrm{G})$. palace'

a. My house is my castle.

b. Rumahku istanaku. 'my house is my

c. Rumahku surgaku. 'my house is my paradise'

Linguistic metaphors in $(G)$ show how house is presented metaphorically in different conceptual mapping. Linguistic metaphor (G.a) conceptualizes the concept of house in terms of the concept of castle. The conceptual mapping is certainly not based on their physical resemblance; rather based on the cultural values of castle which is loaded to the values of house. The cultural values of castle in English refer to the private ownership and, hence, the owner can do anything he wants to do in her/his castle to protect her/his property and safety. The meaning of linguistic metaphor (G.b) and (G.c) is clearly motivated by different conceptual mapping. Linguistic metaphor (G.b) conceptualizes the concept of house more in terms of the values of palace which refers to a state of being the best place. Meanwhile, linguistic metaphor (G.c) is relatively similar in terms of its metaphorical meaning with linguistic metaphor (G.b). Their difference lies in their conceptual mapping where linguistic metaphor (G.c) conceptually includes the Islamic value of what being home should be like.

\section{MARRIAGE IN INDONESIAN: CONCEPTUAL METAPHOR AND ITS CULTURAL COGNITION}

The lexical item 'marriage' provokes a kind of cognitive schema which embraces other related concepts such as love, wedding, husband, wife, family and many others. 
Marriage is culturally perceived by Indonesians as one of points in a life span which they have to pass through and the onset of marriage is symbolized by a wedding party. This concept of marriage is encoded and externalized by the fact that the linguistic expression tidak menikah 'unmarried' is not culturally acceptable as the opposite of the linguistic expression menikah 'married' such as in the following dialog (1).

(1) a : Anda menikah? 'are you married?'

b : Belum, Pak. 'not yet, Sir.'
c $\quad$ : *? Tidak, Pak. 'No, Sir'.

In English, it would be natural to answer No, Sir to the question (1.c). Meanwhile, It is culturally not acceptable - or at least it sounds awkward - in Indonesian to answer tidak, Pak 'No, Sir' to such question. Yet, the choice of the marital status in ID card is between kawin 'married' and belum kawin 'not yet married'. It is not between married and unmarried.

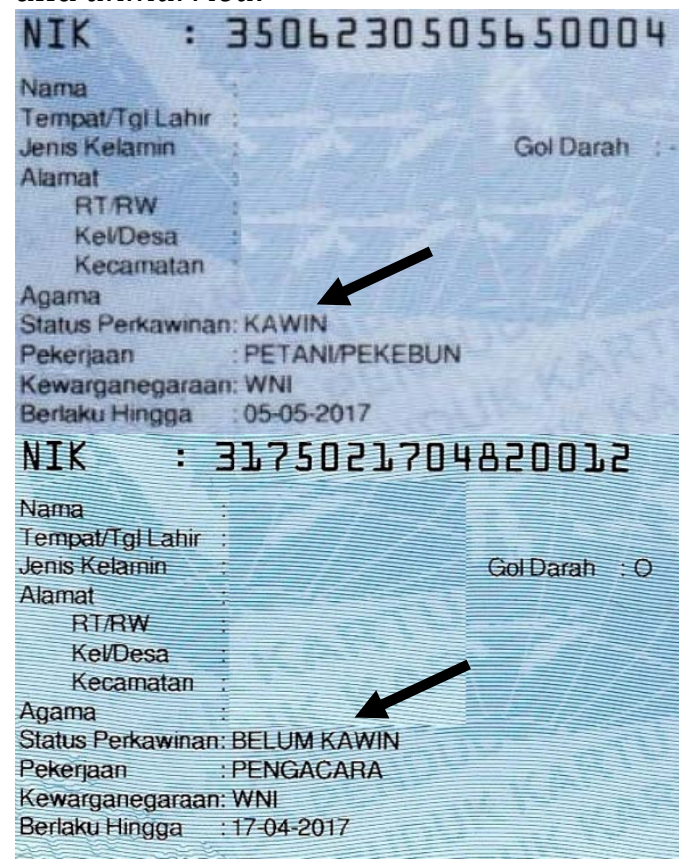

Figure 1. Marital Status in Indonesia's ID Card

The expression not yet married presupposes that $\mathrm{s} /$ he will surely get married someday. Getting married is one of the points in one's life that $s /$ he will surely pass through. In other words, getting married is one of important goals that an Indonesian has to plan to reach. There may be other perspectives which are differently conceptualized by certain cultural groups in Indonesia which, in this case, will form another sub-cultural schema on this matter.

The importance of getting married is encoded and externalized by linguistic metaphors in (2).

(2) a. Dia perawan tua di desa ini. 'She is an old maid in this village'.

b. Dia itu lajang lapuk.

'He is a "rotten bachelor"'

An elderly unmarried woman is metaphorically called as perawan tua or gadis tua 'old maid' or 'spinster' in Indonesian. The linguistic expression perawan tua or gadis tua does not objectively refer to the reality of an elderly woman who is not yet married. It is different from the conceptualization of the other expression such as wanita tua 'elderly woman'. The linguistic expression perawan tua or gadis tua carry a concept of negative values of being unmarried for elderly women. In other words, elderly unmarried woman in Indonesian is culturally perceived as a negative state. This perception also applies to the elderly ummarried man in Indonesian as depicted in the linguistic metaphor lajang lapuk 'rotten bachelor' in (2.b). These linguistic metaphors encode and externalize how getting married is important for both man and woman in Indonesia, moreover getting married at the acceptable age.

The elderly unmarried man and woman are metaphorically mapped in the concept of bing unsold as in the conceptual metaphor ELDERLY UNMARRIED IS UNSOLD. This conceptual metaphor applies to both elderly unmarried woman and elderly unmarried man as in the linguistic metaphors (3).

a. Dia kan lajang lapuk yang tak lakulaku.

'He is an "rotten bachelor" who keeps being unsold'.

b. Saya seorang gadis dewasa, saya takut tidak laku.

'I am a mature girl and I am afraid of being unsold"'

The linguistic metaphors in (3) conceptualize elderly unmarried woman and man as goods which are not yet sold. This metaphorical conceptualization shows how the status of "being married" is higher than 
the status of "being unmarried". Like the unsold goods, an elderly unmarried woman or man is perceived negatively. There must be something wrong which has hindered a woman or man to get married in culturally acceptable range of ages.

In relation to the concept of marriage, the span of life is perceived in terms of the concept of one's social status as in the linguistic metaphors (4) and in terms of the concept that life comprises stages as in the linguistic metaphors (5)

(4) a. Ia mulai berpikir melepas masa lajangnya.

'He starts thinking of taking his bachelor off.

b. Dia ingin segera melepas status jandanya.

'She wants to remove her widow status immediately"'

We can see that in relation to the marriage, the span of life is culturally understood in terms of the concept STATUS, i.e. an accepted position in a social group. This concept-ualization has something to do with (i) the marital status in ID card and (ii) the important concept of marriage in Indonesian society.

(5) a. sebelum menapak jenjang hubungan yang lebih tinggi.

'Before stepping on a higher stage of relationship".

b. Pernikahan membuat hubungan naik ke jenjang yang lebih tinggi dari sekadar pacaran.

'Marriage brings a relationship to a higher stage than just a courtship'

These linguistic metaphors depict a cultural cognition in Indonesian speakers that marriage is a higher stage that courtship. Man and woman are not culturally as well as legally permitted to live together before both get married. This is part of the universal conceptual metaphor that GOOD IS UP. If we combine the conceptual metaphor MARRIAGE IS A STATUS and MARRIAGE IS A HIGHER STAGE, we will find the cultural cognition which underlies the two conceptual metaphor, i.e. that marriage bears a respected social status in Indonesia.
Since marriage is a very important stage in life, the couple are treated extraordinarily on the wedding day. What they need is supplied and served. The couple are conceptualized metaphorically as the king and the queen of the day.

\section{(6) a. Menjadi raja dan ratu sehari pada hari} pernikahan.

'to become a king and a queen on a wedding day".

b. Mahligai pernikahan

"Throne for marriage"

This linguistic metaphor (6) is in line with the previously presented linguistc metaphors. This linguistic metaphors are also supported by the material culture during the wedding day such as wearing best dresses like a king and a queen. Marriage is also metaphorically conceptualized as MARRIAGE IS BUILDING A KINGDOM. The important stage of one's life begins with a wedding party in which the groom and the bride are treated like a king and a queen. They also do lots of symbolic activities which basically indicate how important marriage to the society is.

In terms of how the marriage is managed, marriage is metaphorically conceptualized as doing a journey. The relationship between husband and wife in a marriage is metaphorically conceptualized as MARRIAGE IS A JOURNEY. This kind of conceptual metaphor also applies in English (Kovecses, 2010) and Chinese (Winfred and Ying, 2008). It is very common to find linguistic metaphors which depicts such metaphorical concept-ualization as in (7).

(7) a. Pernikahan adalah suatu perjalanan kehidupan.

'Marriage is a journey of life'.

b. Dalam berumah tangga, kita akan melalui perjalanan panjang dan sangat melelahkan

'In marriage, we will go through a long journey and it is tiring'

c.Pernikahan kita melalui perjalanan panjang yang berliku

'Our marriage have gone through a long winding road' 
However, there exists a sub-conceptual metaphor MARRIAGE IS A JOURNEY. The conceptual metaphor that is cultural-specific in Indonesian, i.e. MARRIAGE IS SAILING. This conceptual metaphor of marriage is depicted in the linguistic metaphors in (8).

(8)a. membangun bahtera pernikahan.

'to build a ship of marriage'.

b. kita harus siap menghadapi gelombang kehidupan life'

'we have to be ready to face a wave of

c. pernikahanku diterpa gelombang badai

'our marriage is hit with a wavestorm'

d. nahkoda rumah tangga

'the captain of the household'

e. Mari kita kayuh bersama biduk rumah tangga

Let's row this vessel of the household together' karan

f. akhirnya bartera rumah tanggaku

'finally my ship of household sank.

g. akhirnya bahtera rumah tangga kami hancur dihempas badai perceraian

'at last, our ship of household was broken down after being hit by the storm of divorce'

There are lots of linguistic metaphors which conceptually map the domain of sailing to the domain of marriage. The way how Indonesian speakers perceive the concept of marriage in terms of the concept of sailing is a culture specific metaphor. It is highly affected by how Indonesian people bodily experience the world around them. Their experience in interaction with sea is the source of the conceptual metaphor of marriage. This conceptual mapping can be presented in Figure 2.

$\begin{array}{ll}\begin{array}{l}\text { SOURCE } \\ \text { SAILING } \\ \text { Ship }\end{array} & \begin{array}{l}\text { TARGET } \\ \text { MARRIAGE } \\ \text { Captain }\end{array} \\ \text { Co-captain } & \begin{array}{l}\text { Household } \\ \text { Husband }\end{array} \\ \text { Sailors } & \text { Wife } \\ \text { Storm } & \text { Kids } \\ \text { Broken/sunk down } & \begin{array}{l}\text { Domestic problem } \\ \text { Broken }\end{array} \\ \text { Waves } & \text { obstacles } \\ \text { Harbor } & \text { Goal of marriage }\end{array}$

Figure 2. The Conceptual Metaphor MARRIAGE IS SAILING

\section{CONCLUSION}

Metaphor is the most intriguing problem in the study of meaning both linguistic meaning and non-linguistic meaning. What has been explored above proves that (i) meaning construction is conceptualization and (ii) it is highly constructed on the basis of how human experiences the reality around them (Dirven and Verspoor, 2004). It is clear that Indonesian people appear to employ similar cognitive faculties as other people from different cultures. However, to a large degree there are experiences that are conceptualized in culturally specific ways. Cognitive Linguistics and Cultural Linguistics are present schools of linguistics which provide promising tools to investigate the relation between language, cognition, and culture..

\section{REFERENCE}

Bloomfield, L. (1933). Language. New York: Henry Holt.

Dirven, R and Verspoor, M. (2004). Cognitive exploration of language and linguistics. Amsterdam: John Benjamins Publishing

Evans, V. (2006). Cognitive linguistics: an introduction. Edinburgh: Edinburgh University Press 
Geeraerts, D. (2006). Introduction, a rough guide to Cognitive Linguistics. In Dirk Geerarts (ed.). Cognitive linguistics: basic reading (pp. 1-28). New York: Mouton de Gruyter

Goatly, A. (1997). The Language of metaphor. London: Routledge

Katz, A. N. (1998). Figurative language and figurative thought. In Katz, A. N. (ed.) Figurative language and thought. New York: OUP

Kövecses, Z. (2010). Metaphor: a practical introduction (2nd Edition). Oxford: Oxford University Press.

Kusmanto, J. (2013). What is it to know the meaning of linguistic expression: an overview from the truth-conditional theory of meaning, pp. 506-519. Prosiding seminar internasional "Studi Bahasa dari Berbagai Perspektif", dalam rangka ulang tahun ke-80 Prof. Soepomo Poedjosoedarmo, Ph.D; 5-6 Desember 2013; University Club, UGM, Yogyakarta.

Kusmanto, J. (2014). Konsep-konsep teoretis tuturan metaforis dalam semantik, pragmatik, dan linguistik kognitif: kajian metalingual lokus makna dan kebermaknaan tuturan metaforis dalam linguistik teoretis. Unpublished doctoral thesis, Postgraduate Program Universitas Sebelas Maret, Surakarta.

Lakoff, G. dan Johnson, M. 1980. Metaphors we live by. Chicago:University of Chicago Press.

Langacker, R. W. 2000. Grammar and conceptualization. Berlin and New York: Mouton de Gruyter.

Lederach, J.P. (1995). Preparing for peace: conflict transformation across cultures. Syracuse, NY: Syracuse University Press.

Locke, J. (1690). An essay concerning human understanding. The Pennsyl-vania State University edition of Electronic Classics Series by Jim Manis (1999).

Livington, P. M. (2015). Naturalism and forms of life: Wittgenstein and the Cratylus. In M. Gustafsson, A. S. Christensen, and Y. Neuman (eds.). Nordic Wittgenstein Review, Vol. 4 (2), pp. 7-38.

Ogden, C. K dan Richards, I. A. (1946). The Meaning of meaning: a study of the influence of language upon thought and of the science of symbolism. $8^{\text {th }}$ edition. New York: A Harvest Book.

Ortony, A. (1993). Metaphor and thought. 2nd edition. Cambridge: Cambridge University Press.

Rosch, E. (1978). Principles of categories. In E. Rosch and B.B.Lloyd (eds.), Cognition and categorization (pp. 27-48). Hillsdale: Lawrence Eelbaum

Sharifian, F. (2011). Cultural conceptualizations and language. Amsterdam: John Benjamins Publishing

Sudaryanto. (1992). Metode linguistik: ke arah memahami metode linguistik. Yogyakarta: Gadjah Mada University Press.

Talmy, L. (1983). How language structures space. In H. Pick \& L. Acredolo (Eds.), Spatial orientation: theory, research, and application (pp. 225-282). New York: Plenum Press.

Winfred, Y. and Ying, L. (2008). A contrastive study of chinese and English metaphors of marriage. LCOM Papers 1, pp. $21-35$. 